Acta vet. scand. 1978, 19, 1-17.

From the Department of Animal Hygiene and the Department of Clinical Radiology, College of Veterinary Medicine, Swedish University of Agricultural Sciences, Uppsala, the Department of Orthopedic Surgery, Karolinska Sjukhuset, Stockholm, Sweden, and the Laboratory for Comparative Orthopaedics, Hospital for Special Surgery, affiliated with the New York Hospital - Cornell University Medical College, New York, USA.

\title{
BONE MINERAL DETERMINATION IN COCCYGEAL VERTEBRAE BY DICHROMATIC PHOTON ABSORPTIOMETRY*
}

\author{
By \\ Roland Zetterholm and Nils Dalén
}

\begin{abstract}
ZETTERHOLM, ROLAND and NILS DALEN: Bone mineral determination in coccygeal vertebrae by dichromatic photon absorptiometry. Acta vet. scand. 1978, 19, 1-17. - A bone scanning device for determination of the bone mineral content in coccygeal vertebrae of cattle is described. The equipment has two gamma radiation sources, consisting of ${ }^{125} \mathrm{I}$ and ${ }^{241} \mathrm{Am}$ with energies of 27 and $60 \mathrm{keV}$, respectively. Absorption is measured by a scintillator photomultiplier detector. The precision of the method has been tested in vivo and found satisfactory $(1.5 \%)$. It is therefore well suited for measuring bone mineral content in coccygeal vertebrae, and thereby the changes which take place in mineral content can be followed.

absorptiometry; bone mineral measurement; calcium metabolism; cattle; gammaray source; phosphorus.
\end{abstract}

Hyperostosis and osteopetrosis are common in cattle (Bane \& Hansen 1961, Kràl 1963, Goronov et al. 1964, Simon 1966, Lachowicz 1967, Krook et al. 1969, 1971, Thomson 1969, Zetterholm 1972). Low serum calcium levels at parturition associated with parturient paresis are also common (Little \& Wright 1925). These disorders indicate that calcium metabolism in cattle is often disturbed. Various parameters in calcium have been investigated such as calcium balance (Forbes et al. 1916, Huffman et al. 1930, Manston 1967, Ramberg Jr. et al. 1970), specific and ash weight of various bones (Hartman \& Meigs 1931, Zetterholm), and calcium levels in blood (Nurmio 1968). Only recent-

* This investigation was supported by The John M. Olin Foundation, the Swedish Medical Research Council, the Swedish Council for Forestry and Agricultural Research, and the Knut and Alice Wallenberg Foundation. 
ly it has been possible to measure, with acceptable precision, the changes in bone mineral in live animals and in human patients (Reed 1960, Cameron \& Sorenson 1963, Nicolic et al. 1971, Wentworth et al. 1971, Schmeling 1972, Fischer et al. 1974, Siemon et al. 1974).

The object of the present study was to develop a method by means of which changes in mineral content can be followed with high precision in live animals.

\section{PRINCIPLE}

Bone mineral and soft tissue have different absorption properties at different photon energies, and the present technique is based on attenuation measurement at two energies, $27 \mathrm{keV}\left({ }^{125} \mathrm{I}\right)$ and $60 \mathrm{keV}\left({ }^{241} \mathrm{Am}\right)$. The transmission of gamma rays by an object depends upon its elementary composition and the wave length distribution. In Fig. 1 the transmission has been plotted as a

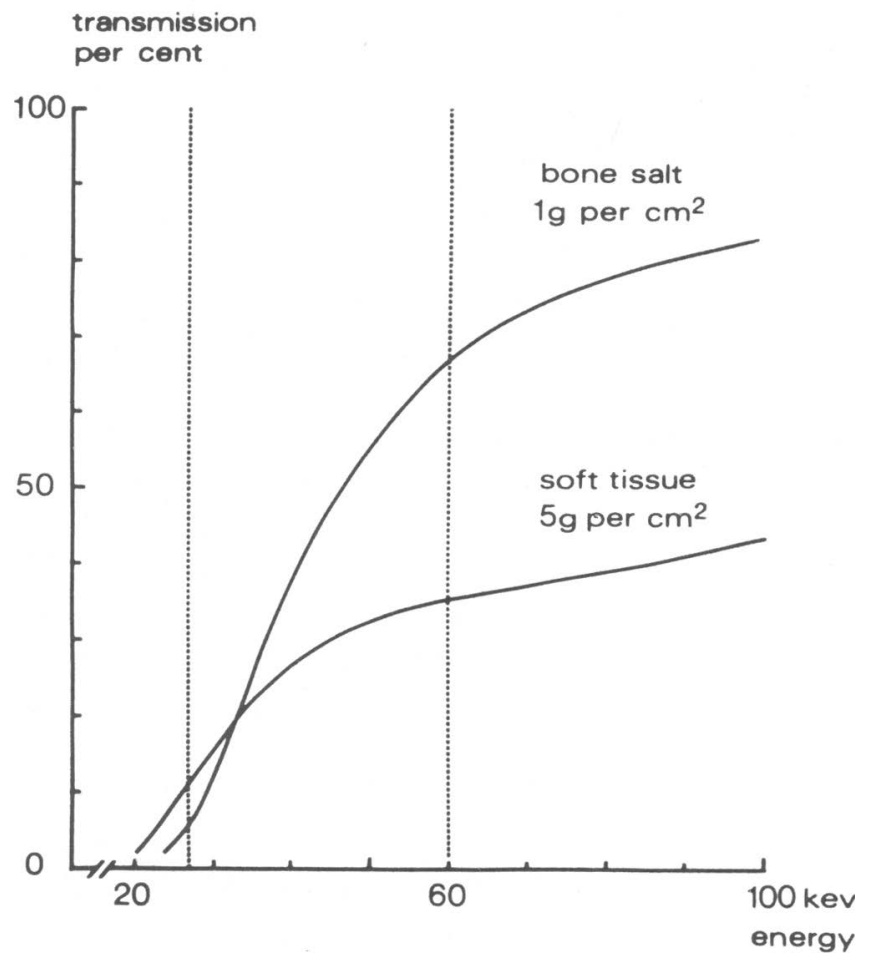

F i g u r e 1. Transmission plotted as a function of gamma ray energy for $1 \mathrm{~g} / \mathrm{cm}^{2}$ of bone mineral and for $5 \mathrm{~g} / \mathrm{cm}^{2}$ of soft tissue (Jacobson 1964). The energies 27 and $60 \mathrm{keV}$ are indicated by dotted lines. 
function of the wave length for $5 \mathrm{~g} / \mathrm{cm}^{2}$ of soft tissue and for $1 \mathrm{~g} / \mathrm{cm}^{2}$ of bone mineral (hydroxyapatite). At other ratios of soft tissue and bone minerals the curves will be different, but never parallel. By comparing the transmission at the two energy levels, a calculation can therefore be made of the proportion of the absorption by the bone mineral and soft tissue, respectively. Hence, the content of bone mineral and soft tissue in the object can be determined. In principle it is achieved by solving a system of two equations, one for each wave length and with two unknowns: the quantities of bone mineral and of soft tissue (Judy 1971, Dissing 1974, 1975). A prerequisite is that the chemical composition of bone mineral and soft tissue is unchanged.

The absorption properties of fat and other soft tissues are not identical, however. A change in the fat content thus gives rise to an error in the bone mineral assay (Sorenson $\mathcal{E}$ Mazess 1970, Zeitz 1972). An increase in the lipid content of soft tissue of $1 \mathrm{~g} / \mathrm{cm}^{2}$ will influence the estimation of bone mineral content by $0.05 \mathrm{~g} / \mathrm{cm}^{2}$ increase of lipid content (Dissing 1974).

The calcium/phosphorus ratio in the bone mineral may also cause an error in the estimated bone mineral content (Judy 1971).

In dichromatic photon absorptiometry the amount of bone mineral is expressed as follows:

when measuring a spot

$\mathrm{g} / \mathrm{c} \mathrm{\textrm {m } ^ { 2 }}$

when scanning perpendicular over a part of a bone

$\mathrm{g} / \mathrm{cm}$

length of the bone

In this case the beam moves continuously perpendicular over the object. A modified technique makes possible several parallel, perpendicular scans over the part of the body to be measured (Jensen et al. 1972).

when scanning a whole bone by several parallel scans g/bo n e

The present technique is built on the third alternative.

\section{Measuring equipment}

\section{MATERIAL}

The system includes a) a gamma ray source, b) a scintillator detector arrangement, c) a scanner arrangement, d) an electronic calculator (Bone Scanner 7102, AB Atomenergi, Studsvik, Nyköping, Sweden), e) a recorder, f) a printer and g) a special fixation device for the object to be measured. 


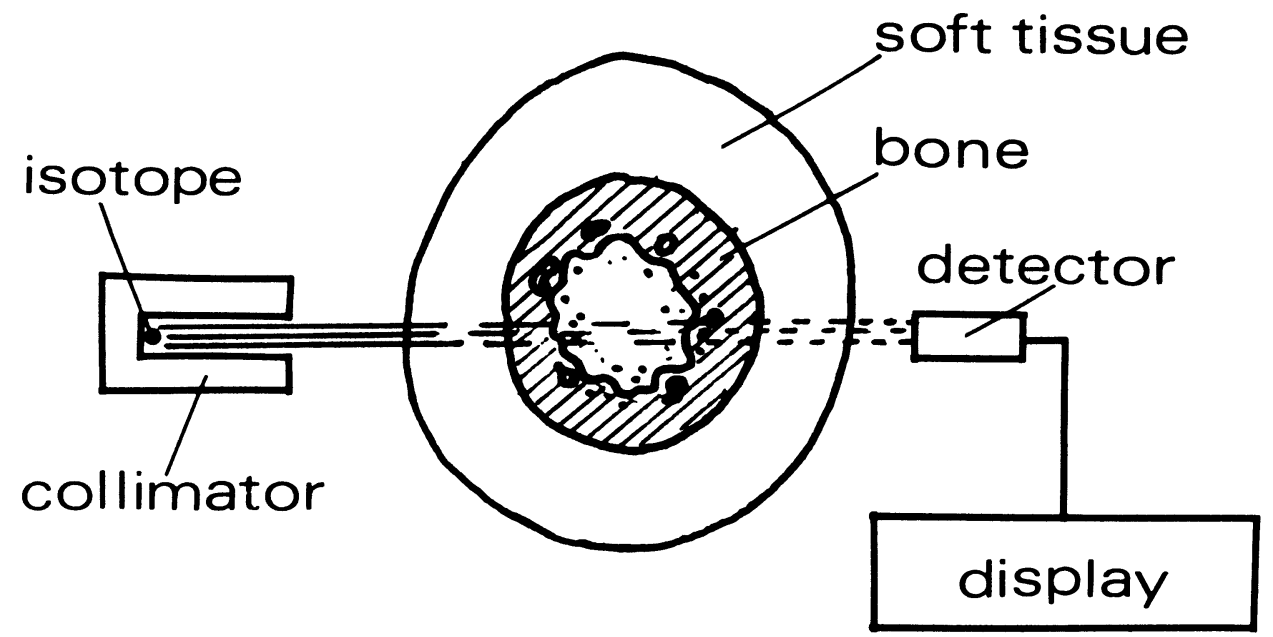

Fig u r e 2. Principle of the measuring equipment.

a) The radiation source consists of ${ }^{125} \mathrm{I}(25 \mathrm{mCi})$ and ${ }^{241} \mathrm{Am}$ (10 $\mathrm{mCi}$ ). The detector aperture is $4 \mathrm{~mm}$ in diameter.

b) The detector consists of a $\mathrm{NaI}$ scintillator crystal $7 \mathrm{~mm}$ in diameter and $2 \mathrm{~mm}$ thick.

c) The scanning arrangement includes two electric motors which move the isotope-holder and detector in vertical and horizontal directions. The isotope-holder and detector are attached to a U-shaped mount to assure parallel movements. The construction of the bone scanner makes it possible to measure in vertical and horizontal directions and to do repeated parallel scans of an object.

Vertical direction:

The isotope-holder/detector moves continuously vertically over the object to be measured. When one scan is completed the isotope-holder/detector moves laterally and the next scan begins.

Horizontal direction:

The isotope-holder/detector moves continuously horizontally over the object to be measured. When one scan is completed the isotope-holder/detector moves vertically and the next scan begins.

d) The electronic calculator integrates the output signal of the logarithmic rate meter, and the signal is converted to a pulse train in an analog-digital converter. Each pulse is recorded 
by an electronic counter, and the result is displayed in digital form.

e) The recorder (Servogor RE 511, AB Transfer, Fack, Sundbyberg, Sweden) plots the absorption in the measured object as a function of time.

f) The printer (Mechanics For Electronics Corp., DPA 12 A, Saven AB, Vaxholm, Sweden) has eight channels which record the isotope, the transmission, and the width of the measured object.

g) The fixation device consists of a special holder for fixation of the tail. Three blocks, each with two wing-nuts, press the tail against an underlying rubber-coated copular channel. Between the two cranial blocks there is a distance large enough to allow two vertebrae to appear. The scanner is raised to a suitable height behind the animal by use of a frame and tackle. The scanner is suspended in four chains, secured two by two, in transverse flat-iron bars, the latter articulating with a longitudinal member in which the tackle is fixed. This arrangement ensures that the scanner follows the movements of the animal very closely.

\section{METHOD}

The instrument is equilibrated in air and water and checked against a standard, i. e. an aluminium alloy which has absorption properties similar to that of bone mineral and which contains $5.6 \% \mathrm{Zn}, 2.5 \% \mathrm{Mg}, 1.6 \% \mathrm{Cu}, 0.5 \%$ each of $\mathrm{Fe}, \mathrm{Si}, \mathrm{Mn}$, Ti, and $0.2 \% \mathrm{Cr}$. The standard is plane-parallel, $5.1 \mathrm{~mm}$ thick, and $20.0 \mathrm{~mm}$ wide.

Ten scans of the standard are made for checking of the scanner.

With the animal in a stand, two coccygeal vertebrae are measured. Their location is marked by clipping the hair over the area to be measured or by freeze-branding or tattooing the skin over the most cranial of the three intervertebral discs. The remaining hair-coat has a negligible effect on the result of the measurements, which are made under epidural anaesthesia with $1-2 \mathrm{ml}$ of $2 \%$ Xylocaine with adrenaline (Astra, Södertälje, Sweden) injected at the level of the first or second intervertebral space. The tail is fixed in the holder. When the beam is moved along the longitudinal axis of the vertebra, a curve is 


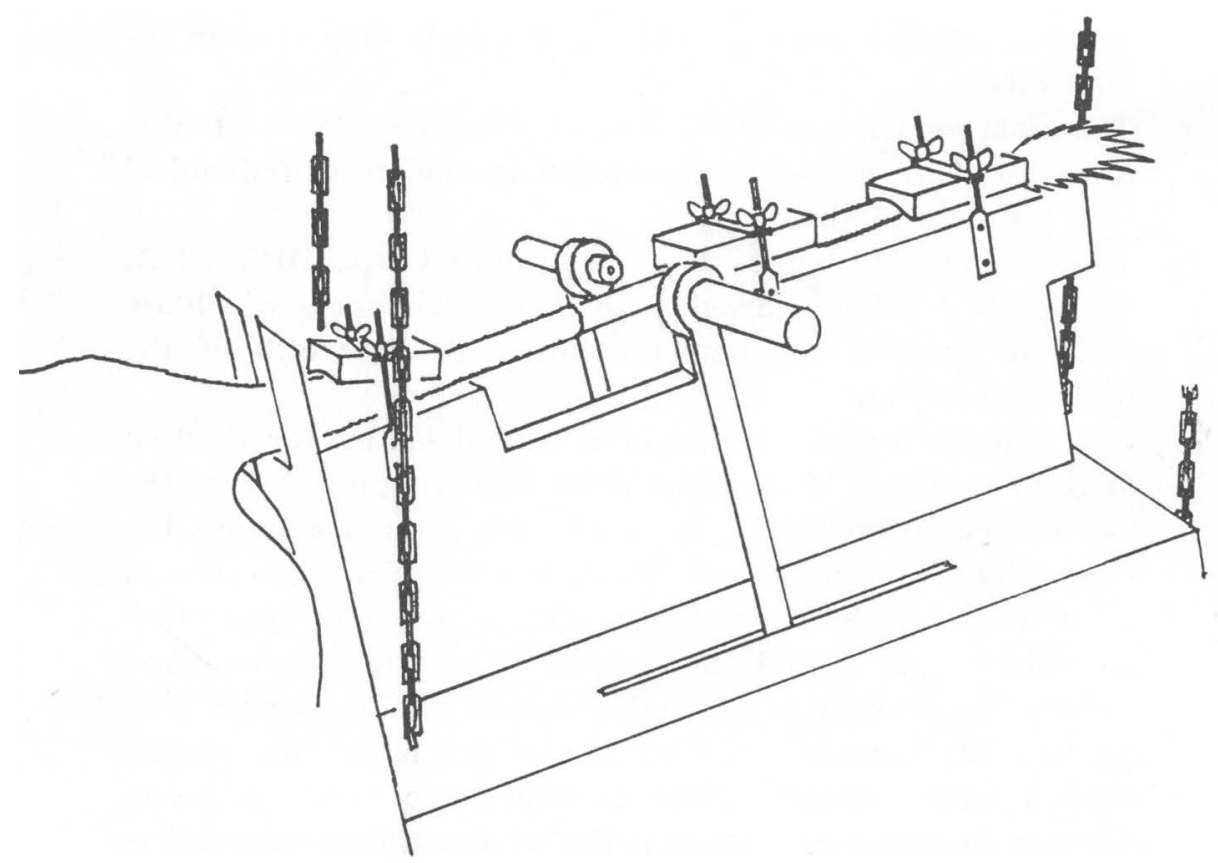

F i g u r e 3. A schematic drawing of the tail holder. It consists of three blocks, each with two wing-nuts, which press the tail against an underlying rubber-coated copular channel. Between the cranial and the middle block a section of the tail is uncovered to permit scanning of slightly more than two vertebrae.

obtained by which the location of the intervertebral discs is determined (Fig. 5). The measurement starts at the disc caudal to the two vertebrae and continues until the disc cranially to these vertebrae has been passed.

The measurements are made in scans perpendicular to and stepwise along the longitudinal axis. The transmission is measured for one isotope at a time. Each segment scanned is $4 \mathrm{~mm}$ wide and each step is $3.2 \mathrm{~mm}$ long. Thus the scans overlap, but the overlapping is compensated for. Fifteen-18 scans are made on each of the two vertebrae of an adult cow. The result figures from each scan are added, and the sum gives the quantity of bone mineral in the two vertebrae.

\section{Precision}

The precision was determined by repeated measurements of the aluminium alloy standard, of a specimen of a coccygeal vertebra, and of the tails of live animals. 


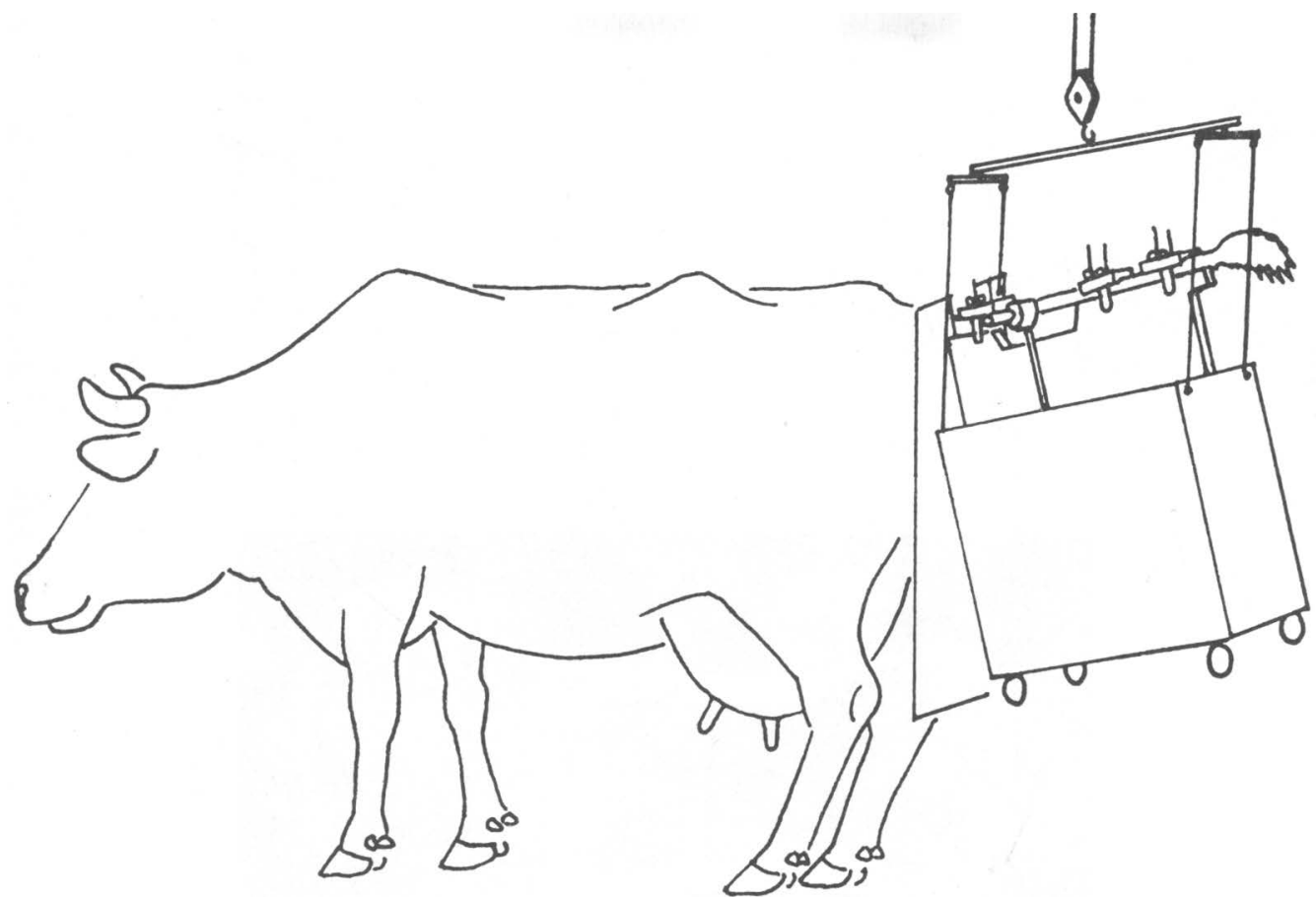

Figur e 4. The scanner raised by tackle to a suitable height behind the animal. To make it as mobile as possible it is suspended in four chains secured, two by two, in transverse flat-iron bars, the latter articulating with a longitudinal shaft secured to the tackle. The movements of the animal are kept to a minimum by a stand and for all practical purposes the fixation of the scanner to the tail is rigid enough.

The aluminium alloy standard was measured 18 times during $8 \mathrm{hrs}$., and on each occasion 10 scans were made and the mean calculated.

Two coccygeal vertebrae, in an intact specimen consisting of a tail from a cow, were measured 15 times on different occasions. The equipment was equilibrated before each measurement.

In 17 live cows two coccygeal vertebrae were measured twice at 24 hrs.' interval.

\section{Accuracy}

The amount of bone mineral in 26 vertebrae in the tails from 10 slaughtered cattle was determined by the present technique. 


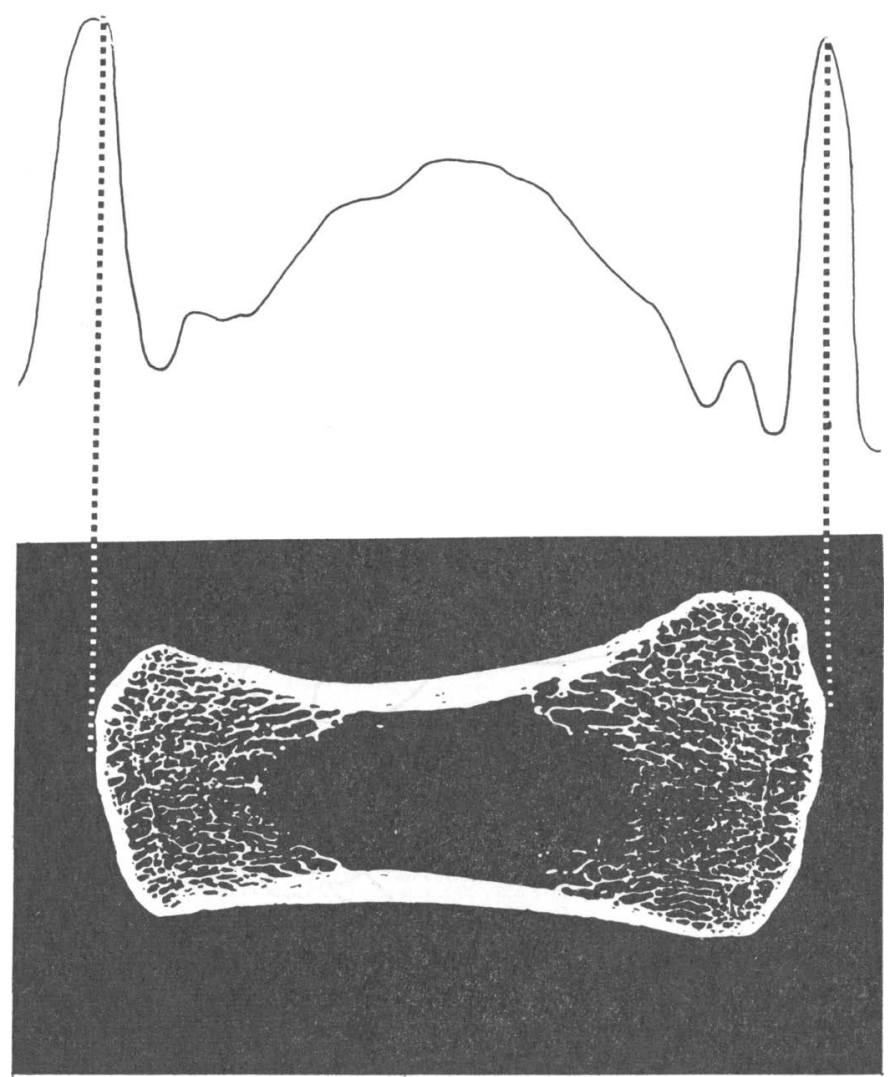

F i g u r e 5. Microdiagram of a $100 \mu$ thick ground section of a coccygeal vertebra. Below is the scanning curve of the vertebra. There is a sudden rise at the transition below the disc and the plate of the vertebra, a gradual fall and rise at midshaft and a sudden drop at the transition to the next disc.

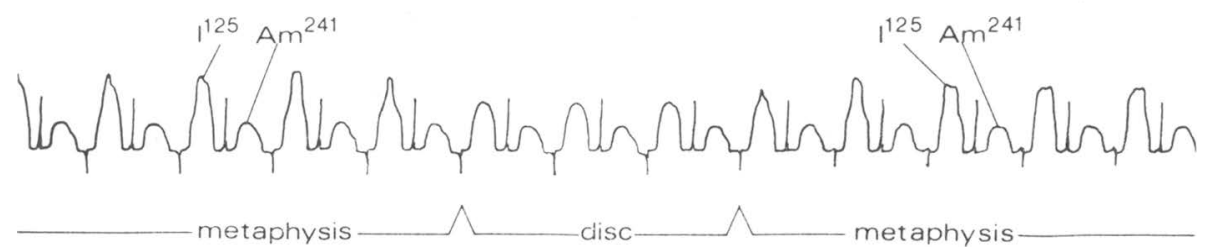

Figure 6. The scanning profiles perpendicular to the axis of the vertebrae. 
The soft tissue was removed from the vertebrae, which were dried in a heat oven to constant weight. After weighing, the vertebrae were ashed using the method of Frank (1976). The calcium content was then determined by the atomic absorption technique, and the phosphorus content determined spectrophotometrically (Taussky \& Shorr 1953).

\section{Calibrating}

The amount of bone mineral in 20 vertebrae in 10 tails from slaughtered cattle was determined by the present technique. Soft tissue was removed from the vertebrae, after which they were ashed in $600^{\circ} \mathrm{C}$ during four days. After weighing the ashed vertebrae, the calibrating coefficient was established by dividing the sum of the weights of the ashed vertebrae with the total sum of the values obtained by scanning. The multiplying of this coefficient with the sum of the scanning results gives the real bone mineral content of the vertebrae.

\section{Radiation}

At $3.5 \mathrm{~cm}$ distance from the isotope the beam diameter is about $1 \mathrm{~cm}$. With a scanning speed of $2 \mathrm{~mm} /$ second the effective exposure time for each increment is $\mathbf{1 0} \mathrm{sec}$. for each isotope.

The dose rate factor for the isotopes (including the effect of low energy $\mathrm{X}$-ray filtering due to the capsule) is about

$1 \mathrm{r} \mathrm{cm}^{2} \mathrm{mCi}^{-1} \mathrm{~h}^{-1}$ for the ${ }^{125 I}(25 \mathrm{mCi})$ and

$0.1 \mathrm{r} \mathrm{cm}^{2} \mathrm{mCi}^{-1} \mathrm{~h}^{-1}$ for the ${ }^{241} \mathrm{Am}(10 \mathrm{mCi})$.

Thus the dose for a complete measurement is $5.5 \mathrm{mrad}\left({ }^{125} \mathrm{I}\right)$ $+0.22 \mathrm{mrad}\left({ }^{241} \mathrm{Am}\right.$ ) (AB Atomenergi, Studsvik, Nyköping, Sweden).

\section{Statistics}

Standard deviation of a single determination ("error of estimation") calculated from duplicate determinations:

$$
\mathrm{s}=\frac{\Sigma \mathrm{d}^{2}}{2 \mathrm{n}}
$$

where $d$ was the difference between two duplicate determinations and $n$ the number of duplicate determinations.

Coefficient of variation or relative standard deviation $(\%)$ :

$$
\mathrm{C}=\frac{\mathrm{s}}{\mathrm{x}} \cdot 100
$$




\section{Precision}

\section{RESULTS}

The results of the measurements of the aluminium alloy standard are given in Table 1.

Table 1. The short time stability of the bone scanner, as determined by repeated measurements of the aluminium alloy standard during 8 hrs.

\begin{tabular}{lcc}
\hline $\begin{array}{l}\text { Hours after } \\
\text { equilibrating }\end{array}$ & $\begin{array}{c}\text { The measured value of the } \\
\text { standard, corresponding to } \\
\text { bone mineral content in } \mathrm{g}\end{array}$ & $\begin{array}{c}\text { Percentage devi- } \\
\text { ation from the mean }\end{array}$ \\
\hline 0 & 0.806 & \pm 0 \\
0 & 0.807 & +0.1 \\
0 & 0.807 & +0.1 \\
0 & 0.807 & +0.1 \\
0 & 0.806 & \pm 0 \\
0 & 0.805 & -0.1 \\
0 & 0.805 & -0.1 \\
0 & 0.806 & \pm 0 \\
0 & 0.805 & -0.1 \\
0 & 0.806 & \pm 0 \\
1 & 0.806 & \pm 0 \\
2 & 0.807 & +0.1 \\
3 & 0.808 & +0.2 \\
4 & 0.805 & -0.1 \\
5 & 0.808 & +0.2 \\
6 & 0.809 & +0.4 \\
7 & 0.806 & \pm 0 \\
8 & 0.807 & +0.1 \\
\hline
\end{tabular}

The results when measuring a specimen of two coccygeal vertebrae in vitro are given in Table 2 .

The methodological error when measuring two coccygeal vertebrae in vivo was $1.48 \%$ (Table 3 ).

\section{Accuracy}

The correlation coefficient between bone mineral content and calcium content per vertebra was 0.98 and to phosphorus 0.99 (Table 4 and Fig. 7).

\section{Calibrating}

The calibrating coefficient was established to 0.29 . 
Table 2. Precision of the bone scanner when measuring two coccygeal vertebrae of a specimen at different times. Mean: $7.676 \quad$ s: 0.099

\begin{tabular}{cc}
\hline $\begin{array}{c}\text { Bone mineral content of } \\
\text { two vertebrae in } \mathrm{g}\end{array}$ & $\begin{array}{c}\text { Percentage deviation from the } \\
\text { mean bone mineral content }\end{array}$ \\
\hline 7.67 & -0.08 \\
7.64 & -0.47 \\
7.78 & +1.49 \\
7.58 & -1.25 \\
7.66 & -0.21 \\
7.71 & +0.44 \\
7.56 & +1.22 \\
7.59 & -1.51 \\
7.25 & -1.12 \\
7.59 & +2.27 \\
7.51 & -1.12 \\
7.69 & -2.16 \\
7.75 & +0.18 \\
& +1.49 \\
\hline
\end{tabular}

Table 3. The methodological error when measuring two coccygeal vertebrae of 17 cows on two occasions at $24 \mathrm{hrs}$.' interval. Methodological error $1.48 \%$.

\begin{tabular}{rrr}
\hline $\begin{array}{c}\text { Bone mineral content of } \\
\text { the two vertebrae in } \mathrm{g}\end{array}$ & $\begin{array}{c}\text { Percentage deviation } \\
\text { from the mean bone } \\
\text { mineral content }\end{array}$ \\
\hline 1st measurement & 2nd measurement & \\
\hline & & \\
8.78 & 4.71 & 1.47 \\
6.70 & 8.58 & 1.38 \\
10.54 & 6.17 & 0.32 \\
6.85 & 10.66 & 1.13 \\
6.44 & 7.07 & 3.30 \\
7.57 & 6.64 & 3.05 \\
10.60 & 7.71 & 1.83 \\
6.44 & 10.52 & 0.75 \\
6.36 & 6.45 & 0.15 \\
8.66 & 6.41 & 0.78 \\
6.12 & 8.55 & 1.27 \\
5.74 & 6.05 & 1.15 \\
4.84 & 5.64 & 1.75 \\
10.32 & 4.66 & 3.78 \\
6.43 & 10.19 & 1.26 \\
5.21 & 6.13 & 4.77 \\
& 5.22 & 0.19 \\
\hline
\end{tabular}


T a b l e 4. Bone mineral content as determined by dichromatic photon absorptiometry, calcium content as determined by atomic absorption, and phosphorus content spectrophotometrically for 26 vertebrae.

\begin{tabular}{ccc}
\hline Bone mineral, g & Ca, g & P, g \\
\hline 4.48 & 1.797 & 0.865 \\
3.65 & 1.515 & 0.825 \\
1.70 & 0.660 & 0.337 \\
1.32 & 0.492 & 0.275 \\
3.16 & 1.342 & 0.688 \\
3.03 & 1.169 & 0.584 \\
2.71 & 1.039 & 0.531 \\
2.32 & 0.907 & 0.444 \\
6.05 & 2.631 & 1.256 \\
5.10 & 2.279 & 1.093 \\
6.15 & 2.565 & 1.238 \\
5.44 & 2.370 & 1.135 \\
2.31 & 1.040 & 0.502 \\
1.83 & 0.760 & 0.394 \\
2.92 & 1.185 & 0.590 \\
2.51 & 1.051 & 0.540 \\
2.41 & 0.883 & 0.431 \\
2.00 & 0.704 & 0.362 \\
3.59 & 1.310 & 0.729 \\
3.26 & 1.190 & 0.650 \\
2.59 & 0.992 & 0.593 \\
2.35 & 0.833 & 0.472 \\
6.42 & 2.222 & 1.288 \\
5.31 & 2.064 & 1.010 \\
2.44 & 0.952 & 0.513 \\
1.94 & 0.714 & 0.375 \\
\hline
\end{tabular}

\section{DISCUSSION}

The present study demonstrates that the bone mineral content in coccygeal vertebrae of cattle can be determined in vivo by dichromatic photon absorptiometry. In this way changes in the mineral content can be registrated. The methodological error is $1.5 \%$. It is partly statistical in nature, and it is therefore possible to keep it low by using small steps in scanning and by expressing the result as a mean value of the scanning of two vertebrae. The method is precise enough to detect small changes in the bone mineral content.

However, one must know that there are sources of error. One has to consider false differences between the result of sub- 


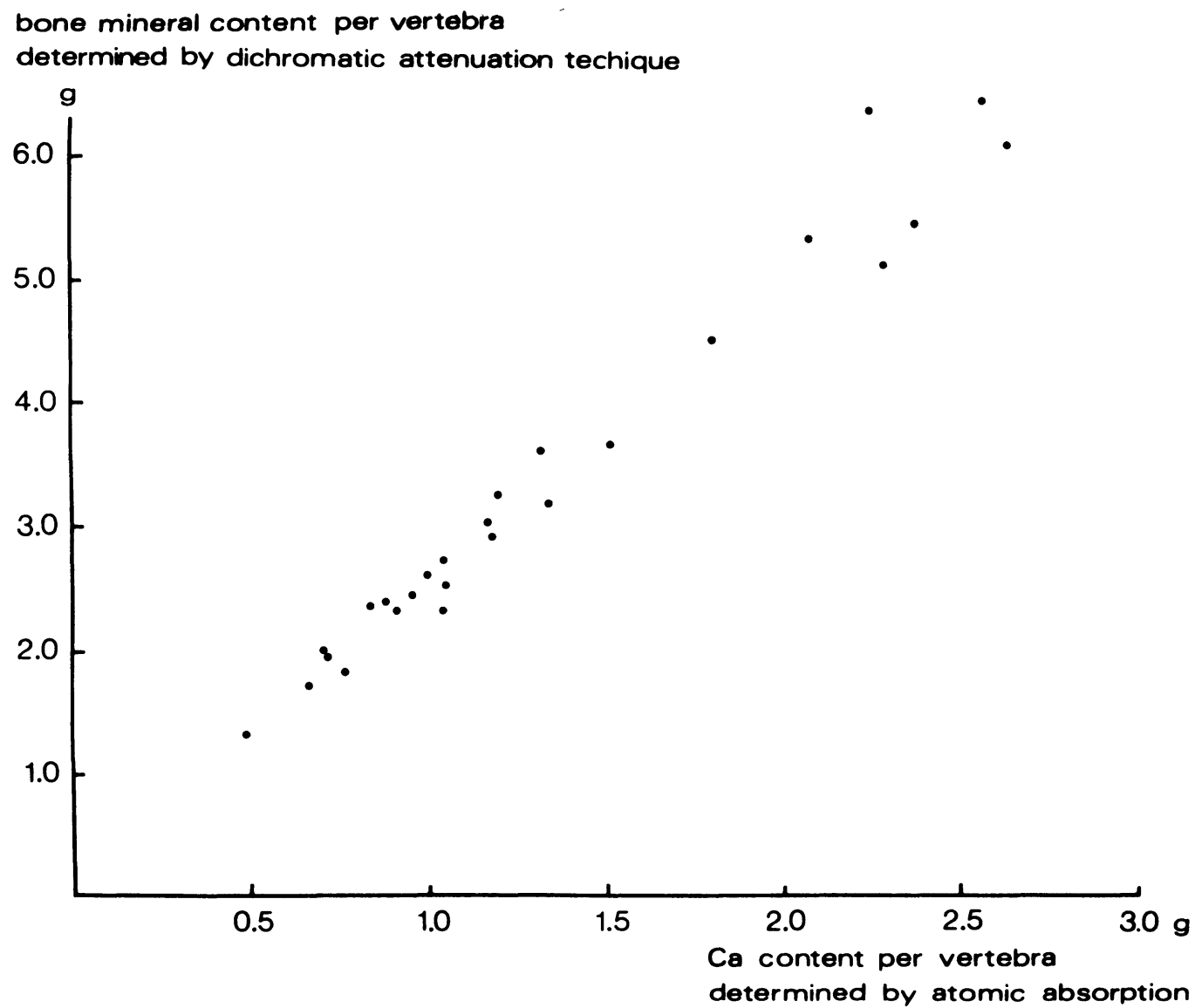

Figure 7. Correlation between bone mineral content found by dichromatic photon absorptiometry and $\mathrm{Ca}$ determined by atomic absorption.

sequent measurements of bone mineral. Theoretically such false differences can occur. Changes in the amount of fat in and around the bone may cause false reading. A change in the calcium/phosphorus ratio from one measurement to the other may also give rise to a false difference. However, it is very unlikely that these prerequisites for the occurrence of false results will be present.

The reason why the coccygeal vertebrae were chosen as the site of bone mineral determination was as follows. The quanta flux of the radiation source is limited, and the tail of a cow 
is thin enough to be penetrated by the radiation to a sufficient degree. The vertebral column is apparently the best place to measure bone resorption (Benzie et al. 1955, Sansom 1969, Blincoe et al. 1973, Siemon \& Moodie 1974). The coccy is a part of the vertebral column, which does not take part in weightbearing. Trabecular bone undergoes resorption more easily and quicker than cortical bone because of its relatively larger surface area (Bauer et al. 1929, Ellinger et al. 1952). The vertebral bodies consist to a high percentage of trabecular bone and they are well defined units separated by the intervertebral discs. The tail can easily be anaesthetized, securely fixed and attached to the measuring device.

It must be taken into account that the two coccygeal vertebrae, the bone mineral of which is measured, may not be entirely representative of the overall bone mineral changes in the skeleton (Dalén 1973). It would therefore be desirable to make determination of the bone mineral content also at other sites, e. g. the metatarsal or phalangeal bones. However, this would require other isotopes with radiation of higher energy (Reed 1966, Mazess et al. 1970), and restraining of the animal would be a much greater problem.

With the present technique changes in bone mineral content of the coccygeal vertebrae can be determined in vivo without discomfort to the animal. The method therefore seems well suited for measuring changes in bone mineral content in cattle on various nutritional regimens.

\section{REFERENCES}

Bane, A. \& H.-J. Hansen: Spinal changes in the bull and their significance in serving inability. Cornell Vet. 1961, 52, 362-384.

Bauer, W., J. C. Aub \& F. Albright: Studies of calcium and phosphorus metabolism. V. A study of the bone trabeculae as a readily available reserve supply of calcium. J. exp. Med. 1929, 49, $145-161$.

Benzie, D., A. W. Boyne, A. C. Dalgarno, J. Duckworth, R. Hill \& D. $M$. Walker: Studies of the skeleton of the sheep. I. The effect of different levels of dietary calcium during pregnancy and lactation on individual bones. J. agric. Sci. (Camb.) 1955, 46, 425-439.

Blincoe, C., A. L. Lesperance \& V. R. Bohman: Bone magnesium, calcium and strontium concentrations in range cattle. J. Anim. Sci. 1973, 36, 971-975.

Cameron, J. R. \& J. Sorenson: Measurement of bone mineral in vivo. Science 1963, 142, 230-232. 
Dalén, N.: Bone mineral assay. Measuring sites: clinical applications. Thesis. Karolinska Institutet, Stockholm, Sweden 1973, pp. 86.

Dissing, E.: Performance of a dichromatic and simultaneously operating gamma ray absorptiometer. AB Atomenergi, Studsvik, Nyköping, Sweden. AE-489, 2, 1974, 19-39.

Dissing, E.: Statistic performance of dichromatic scanners for absorptiometric determination of bone mineral content using low energy gamma rays. AB Atomenergi, Studsvik, Nyköping, Sweden. AE-508, 1975, $14 \mathrm{pp}$.

Ellinger, G. M., J. Duckworth, A. C. Dalgarno \& M. H. Quenouille: Skeletal changes during pregnancy and lactation in the rat. Effect of different levels of dietary calcium. Brit. J. Nutr. 1952, $6,235-253$.

Fisher, G. L., J. A. Schwind, T. D. Lee \& M. Goldman: A photon absorptiometer for in vivo and in vitro measurement of small animal bone density. Bio-med. Engng. 1974, 196-199, 213.

Forbes, E. B., F. M. Beegle, C. M. Fritz, L. E. Morgan \& S. N. Rhue: The mineral metabolism of the milk cow. Bull. Ohio agric. exp. Sta. 1916, 295, 323-333.

Frank, A.: Automated wet ashing and multi-metal determination in biological materials by atomic-absorption spectrometry. Z. analyt. Chem. 1976, 279, 101-102.

Goronov, Z., On. Nejtschev, N. Budorov, K. Kojtschev \& K. Binew: Untersuchungen einiger Erkrankungen der Zehenknochen bei Zuchtbullen und -Kühen. (Investigations of some digital bone diseases in breeding bulls and cows). Nauč. Tr. vissh. vet. med. $1964,13,238-239$.

Hartman, A. M. \& E. B. Meigs: Calcium assimilation as indicated by bone analysis in long-time experiments. J. Dairy Sci. 1931, 14, $322-336$.

Huffman, C. F., C. S. Robinson \& O. B. Winter: The calcium and phosphorus metabolism of heavily milking cows. J. Dairy Sci. 1930, $13,432-448$.

Jacobson, B.: X-ray spectrophotometry in vivo. Amer. J. Roentgenol. 1964, 91, 202.

Jensen, H., C. Christiansen, F. Lindbjerg \& O. Munck: The mineral content in bone measured by means of $27.5 \mathrm{keV}$ radiation from I-125. Acta radiol. (Stockh.) Suppl. 313, 1972, 214-220.

Judy, P. F.: A dichromatic attenuation technique for in vivo determination of bone mineral content. Thesis. University of Wisconsin, Madison, Wisconsin 1971, pp. 127.

Kràl, E.: Digital bone lesions in bulls. Sb. vys. Sk. zemêd. les. Fac. Brne. B. Spisy Fak. vet., Brno 1963, 11, 367.

Krook, L., L. Lutwak \& K. McEntee: Dietary calcium, ultimobranchial tumors and osteopetrosis in the bull. Syndrome of calcitonin excess? Amer. J. clin. Nutr. 1969, 22, 115-118.

Krook, L., L. Lutwak, K. McEntee, P.-A. Henriksson, K. Braun \& S. Roberts: Nutritional hypercalcitoninism in bulls. Cornell Vet. $1971,61,625-639$. 
Lachowicz, S.: X-ray examination of bone changes in hoof diseases of cattle. Weterynaria, Wroclaw 1967, 21, 120-121.

Little, W. L. \& N. C. Wright: The aetiology of milk fever in cattle. Brit. J. exp. Path. 1925, 6, 129-134.

Manston, R.: The influence of dietary calcium and phosphorus concentration on their absorption in the cow. J. agric. Sci. (Camb.) $1967,68,263-268$.

Mazess, R. B., M. Ort, P. Judy \& W. Mather: Absorptiometric bone mineral determination using ${ }^{153} \mathrm{Gd}$. Bone Measurement Conf., Chicago, Ill., May 1970. Proc. USAEC CONF - 700515, 1970, $308-312$.

Nicolic, V., U. Bego, H. Cerovac, J. Hancevic, P. Rudan \& V. Nutrizio: Méthode de détermination du contenu des mineraux dans le squelette des animaux domestiques par la mésure de l'absorption des rayons gamma. (Method of mineral content determination in the skeleton of domestic animals by means of gamma ray absorption). Bull. Ass. Anat. (Nancy), (56 Congrès) 1971, $649-655$.

Nurmio, $P .:$ On plasma calcium regulation in paresis puerperalis hypocalcemia in cattle. Acta vet. scand. 1968, 9, Suppl. 26. 100 pp.

Ramberg Jr., C. F., G. P. Mayer, D. S. Kronfeld, J. M. Phang \& M. Berman: Calcium kinetics in cows during late pregnancy, parturition and early lactation. Amer. J. Physiol. 1970, 219, 1166-1177.

Reed, G. W.: Studies of bone mineralisation. A. R. Brit. Emp. Cancer Campgn. 1960, 38, 489.

Reed, G. W.: The assessment of bone mineralisation from the relative transmission of Am-241 and Cs-137 radiations. Phys. in Med. Biol. 1966, 11, 174.

Sansom, B. F.: Variations in the relative cortical mass of tail bones of cows during pregnancy and lactation. Brit. vet. J. 1969, 125, $454-457$.

Schmeling, P.: Measurement of bone content using radiation sources. An annotated bibliography. AB Atomenergy, Studsvik, Nyköping, Sweden. AE-454, 1972, 63 pp.

Siemon, N. J. \& E. W. Moodie: Reproducibility of specific gravity estimations on bone samples from different sites of cattle and sheep. Calcif. Tiss. Res. 1974, 15, 181-188.

Siemon, N. J., E. W. Moodie \& D. F. Robertson: The determination of bone density by radiation absorption. Calcif. Tiss. Res. 1974, $15,189-199$.

Simon, G.: Pathological changes in the pedal bone of the cow. Refuah. vet. $1966,23,186-195$.

Sorenson, J. A. \& R. B. Mazess: Effects of fat bone mineral measurements. Bone Measurement Conf., Chicago, Ill., May 1970. Proc. USAEC CONF - 700515, 1970, 255-262.

Taussky, Hertha H. \& E. Shorr: A microcolorimetric method for the determination of inorganic phosphorus. J. biol. Chem. 1953, 202, 675-685.

Thomson, R. G.: Vertebral body osteophytes in bulls. Path. Vet. 1969, 6, Suppl. 6, 46 pp. 
Wentworth, R. A., F. A. Kallfelz, F. L. Hiltz, H. Schryver, B. Scheffy \& L. P. Krook: In vivo estimation of bone mineral content: A research and diagnostic technique for veterinary medicine. Amer. J. vet. Res. 1971, 32, 985-992.

Zeitz, L.: Effect of subcutaneous fat on bone mineral content measurements with the "single-energy" photon absorptiometry technique. Acta radiol. (Stockh.) 1972, 11, 401-410.

Zetterholm, R.: Osteopetrosis and hyperostosis in cattle. Proc. 2nd Int. Conf. vet. Radiologists, Stockholm 1970. Acta radiol. (Stockh.) 1972, Suppl. 319, 107-116.

\section{SAMMANFATTNING \\ Benmineralmätningar utförda med dikromatisk foton absorptiometri $i$ svanskotor hos nötkreatur.}

Den kortvågiga, elektromagnetiska strålningens absorption $\mathrm{i}$ ben och mjukdelar är dels beroende av den energi fotonen har, dels vävnadens kemiska sammansättning. Om fotonen har en given energi blir absorptionen enbart beroende av vävnadens sammansättning och mängd. Den teknik som här användes bygger på absorption av fotoner med skilda våglängder, $27 \mathrm{keV}\left({ }^{125} \mathrm{~J}\right)$ resp. $60 \mathrm{keV}\left({ }^{241} \mathrm{Am}\right)$.

Absorptionen i benvävnad och mjukvävnad är en funktion av fotonens energi. Vid en given mängd benvävnad/mjukvävnad förhåller sig absorptionskurvorna till varandra på ett speciellt sätt. Vid en ändrad mängd benvävnad/mjukvävnad blir kurvorna annorlunda, men aldrig parallella. Genom att jämföra absorptionen vid olika energinivåer kan alltså absorptionen $i$ ben- respektive mjukvävnad bestämmas. Därav följer att mängden benvävnad i ett objekt kan uppmätas.

Mätutrustningen består av en strålkälla, en detektor, en scanner, en elektronisk kalkylator (Bone Scanner 7102, AB Atomenergi, Studsvik, Nyköping, Sweden), en skrivare, en printer och en speciellt konstruerad hållare. Strålkällan utgörs av ${ }^{125} \mathrm{~J}(25 \mathrm{mCi})$ och ${ }^{241} \mathrm{Am}$ (10 mCi). Detektorn består av en scintillator med en NaJ-kristall. Scannerns konstruktion möjliggör mätning $i$ vertikal och horisontal riktning. Mätningen utföres på svanskotor, och den speciella hållaren är konstruerad för fixering av svansen. Vanligen mätes två kotor under epidural anestesi. Mätningarna göres vinkelrätt mot och stegvis längs kotornas longitudinella axel. Mätningarna börjar vid den disk som ligger närmast kaudalt om de två kotorna. 15-18 „scans“ görs på varje kota. Summan av erhållna värden för varje „scan“ anger kvantiteten benmineral i den eller de mätta kotorna. Metodfelet har fastställts genom upprepade mätningar av en standard bestående av en Al-legering samt genom upprepade mätningar av svanspreparat och svansar på levande nötkreatur. Metodfelet vid mätningarna av två svanskotor befanns vara $1.5 \%$.

(Received April 28, 1977).

Reprints may be requested from: The Department of Animal Hygiene, Animal Science Centre, College of Veterinary Medicine, S-750 07 Uppsala 7 , Sweden. 